\title{
Vonoprazan in the management of gastric/peptic ulcers: a systematic review of safety data
}

\author{
Joaquim Prado P. Moraes-Filhoํ, Gerson Domingues², Décio Chinzon ${ }^{1}$, Juliana Leite Soares Guedes ${ }^{3}$, \\ Cláudia Yang Santos ${ }^{3}$, Schlioma Zaterka ${ }^{1}$ \\ ${ }^{1}$ Gastroenterology Department, Medical School, University of Sao Paulo, Sao Paulo, SP, Brazil \\ ${ }^{2}$ Gastroenterology Department, Medical School, State University of Rio de Janeiro, Rio de Janeiro, RJ, Brazil \\ ${ }^{3}$ Takeda Pharmaceuticals, Brazil
}

Gastroenterology Rev 2022; 17 (4): 266-273

DOI: https://doi.org/10.5114/pg.2022.112777

Key words: oesophagitis, systematic review, gastroesophageal reflux.

Address for correspondence: Joaquim Prado P. Moraes-Filho, Rua João Moura 625 cj 174 CEP 05412-001, Sao Paulo, SP, Brazil, e-mail: joaquimprado19@gmail.com

\begin{abstract}
Introduction: Although potassium-competitive acid blockers (P-CABs) prompted safety concerns when first developed, they ultimately proved to have a favourable safety profile.

Aim: To assess the safety of vonoprazan in the management of gastroesophageal reflux disease (GERD), peptic ulcers, or gastroduodenal mucosal lesions induced by chronic use of aspirin or non-steroidal anti-inflammatory drugs (NSAIDs).

Material and methods: From March to June 2021, a literature search was conducted using Medline via PubMed, Cochrane library, Lilacs, SciELO, and Centre for Reviews and Dissemination (CRD) electronic databases. After applying the eligibility criteria, 10 studies were included in this review. Of these 10 articles, vonoprazan was used as initial therapy in 6 and as maintenance therapy in 4. Adverse event rates were similar for vonoprazan and proton-pump inhibitors (PPIs).

Conclusions: Our findings suggest that vonoprazan is a safe option for the management of erosive oesophagitis, gastric/ peptic ulcers, or peptic ulcers induced by chronic use of aspirin or NSAIDs.
\end{abstract}

\section{Introduction}

Acid-related diseases result from distinct but overlapping pathogenic mechanisms that involve acid effects on an oesophagogastric duodenal mucosa with diminished defence. While gastroesophageal reflux disease (GERD) represents the most frequently observed acid-related disorder, peptic ulcers and ulcers caused by the use of non-steroidal anti-inflammatory drugs (NSAIDs) and acetylsalicylic acid (ASA) are also important acid-related diseases [1, 2].

The symptoms associated with acid-related diseases affect health-related quality of life and work productivity. Serious complications such as oesophageal stricture, ulceration, Barrett's oesophagus, or cancer may develop without effective treatment [3].

Proton pump inhibitors (PPIs) were introduced in the late 1980 s and dramatically improved gastric acid-related conditions [4]. Nowadays, PPIs dominate in acid-related disease management worldwide [5-8]. However, despite their efficiency, PPIs may exhibit delay in symptom improvement, low bioavailability, fast metabolism, drug interactions, variable sustainability of acid suppression, enteric-coated pharmaceutical form, and more effective action on the nocturnal acidity breakthrough, among other limitations that together lead to unmet acid-related disease management needs [9]. In this scenario, potassium-competitive acid blockers (P-CABs) have emerged to promote a better antisecretory effect that addresses these unmet needs, including the rapid improvement of symptoms, refractory GERD, and nocturnal acid reflux related to disease management [10].

The first P-CAB used in clinical practice was revaprazan, and it has been available in South Korea and India since 2007, but there are no reports that it is more effective than PPIs for acid-related conditions [4]. Vonoprazan became available in Japan in 2015 to treat gastric ulcer, duodenal ulcer, and erosive oesophagitis, and to prevent low dose aspirin- or NSAID-induced peptic ulcer recurrence, and tegoprazan was approved as 
a treatment for GERD in South Korea in July 2018 [4, $11,12]$

\section{Aim}

Because of the advent of new P-CABs and their efficacy profile, we conducted a systematic review to assess the safety of vonoprazan in the management of patients diagnosed with GERD oesophagitis, with peptic ulcers, or those with ulcers induced by chronic use of aspirin or NSAIDs.

\section{Material and methods \\ Study design}

In order to answer to the proposed objectives, a systematic review of the available literature was conducted. The research question was defined according to the PICO model (population; intervention; control; outcome) [13]. Studies that evaluated vonoprazan safety when used as a treatment strategy for patients diagnosed with GERD oesophagitis were searched, along with studies that concerned vonoprazan treatment of peptic ulcers induced by chronic use of aspirin or NSAIDs or gastric/duodenal ulcer.

\section{Search strategy}

A literature search was conducted on 20 June 2021 using Medline via PubMed, Cochrane library, Lilacs, Sci-
ELO, and Centre for Reviews and Dissemination (CRD) electronic databases for the terms listed in Table I. Additionally, manual searches of bibliographic references and abstracts of selected publications complemented the electronic searches.

\section{Eligibility and inclusion and exclusion criteria}

Studies to be considered eligible should meet the following inclusion criteria: meta-analyses, systematic reviews and phase III or IV randomized controlled trials (RCTs), or observational studies; studies involving patients using vonoprazan to treat GERD oesophagitis, gastric/duodenal ulcers or those in chronic use of aspirin or NSAIDs; and analysis with potassium pump inhibitor as a comparator or without comparator and safety endpoints. Furthermore, all articles under at least one of the following conditions were excluded: narrative reviews, guidelines, consensus articles, editorials, case reports, or case series; studies involving patients with Helicobacter pylori or with ulcers due to endoscopic submucosal dissection; studies using animal models; and articles published in other languages than English, Portuguese, and Spanish.

\section{Quality assessment}

Risk of bias of the included studies was evaluated using the Cochrane tool for assessing the risk of bias,

Table I. Search queries

\begin{tabular}{|c|c|}
\hline Database & Search strategy \\
\hline Pubmed & 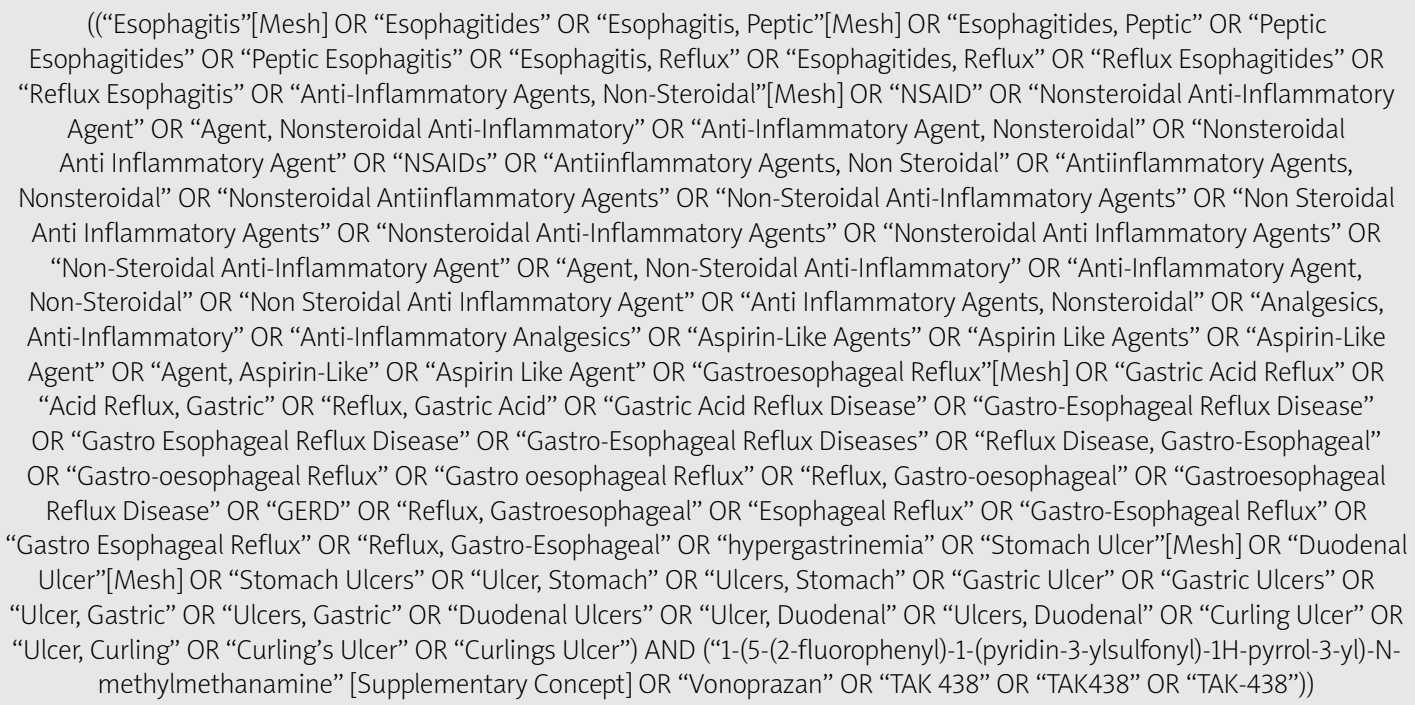 \\
\hline Lilacs & (“Vonoprazan”) \\
\hline SciELO & (“Vonoprazan”) \\
\hline CRD & (“Vonoprazan”) \\
\hline Cochrane & ("Vonoprazan") \\
\hline
\end{tabular}

CDR - Centre for Reviews and Dissemination, LILACS - Literatura Latino-Americana e do Caribe em Ci ncias da Saúde. 
the Risk of Bias 2 (RoB 2) tool, or the Joanna Briggs Institute checklist for quasi-experimental studies [14, 15]

\section{Data synthesis}

Data extracted from the included studies were synthesized and reported as tables and figures. Additionally, information was stratified according to a comparator arm (none or PPI).

\section{Results}

\section{Study selection}

A total of 130 studies were retrieved from the database, including duplicates. After applying eligibility criteria, 32 articles were selected for full-text reading by 2 reviewers. Finally, 10 studies were included in this review (Figure 1).

\section{Characteristics of studies}

Table II shows the included studies list and the description of their general characteristics according to the comparator type. Of the 10 articles included in the analysis, 7 were compared to lansoprazole, 2 against different doses of vonoprazan, and 1 in a single arm. The number of patients ranged from 19 to 850 , totalling 3618 patients included in the selected studies. Patients were followed for a period of up to 52 weeks.

\section{Vonoprazan use as initial therapy}

Six studies considering the use of vonoprazan as initial therapy were included in the analysis [16-21]. Information about treatment-emergent adverse events is shown in Table III. Several adverse events with frequen- cy $>5 \%$ reported in the studies are described in Table IV. Okanobu et al. reported the absence of adverse events during the study period but did not provide details on assessments, so it was not described in respective tables [16].

Similar frequencies of treatment-emergent adverse events, serious adverse events, and those leading to treatment discontinuation were reported by the studies (Table III). Gastrointestinal disorders were the most frequently observed events (Table IV).

\section{Vonoprazan use as maintenance therapy}

Considering vonoprazan as maintenance therapy, a total of 4 studies were included in the analysis [2225]. Table $V$ shows information about treatment-emergent adverse events, while several adverse events with frequency $>5 \%$ reported in the studies are described in Table VI. As observed for vonoprazan use as initial therapy, a similar pattern of adverse events occurrence was found in several comparator arms. Nasopharyngitis was the most frequently observed event (Table VI).

\section{Discussion}

This systematic review was conducted to assess the safety of vonoprazan in the management of patients diagnosed with GERD oesophagitis, gastric/peptic ulcers, or peptic ulcers induced by chronic use of aspirin or NSAIDs. Considering the drug efficacy profile and safety data available in the current literature, this study adds important knowledge to disease management.

P-CABs were first described in the 1980s with $\mathrm{SCH} 28080$. This compound showed the capacity to in-

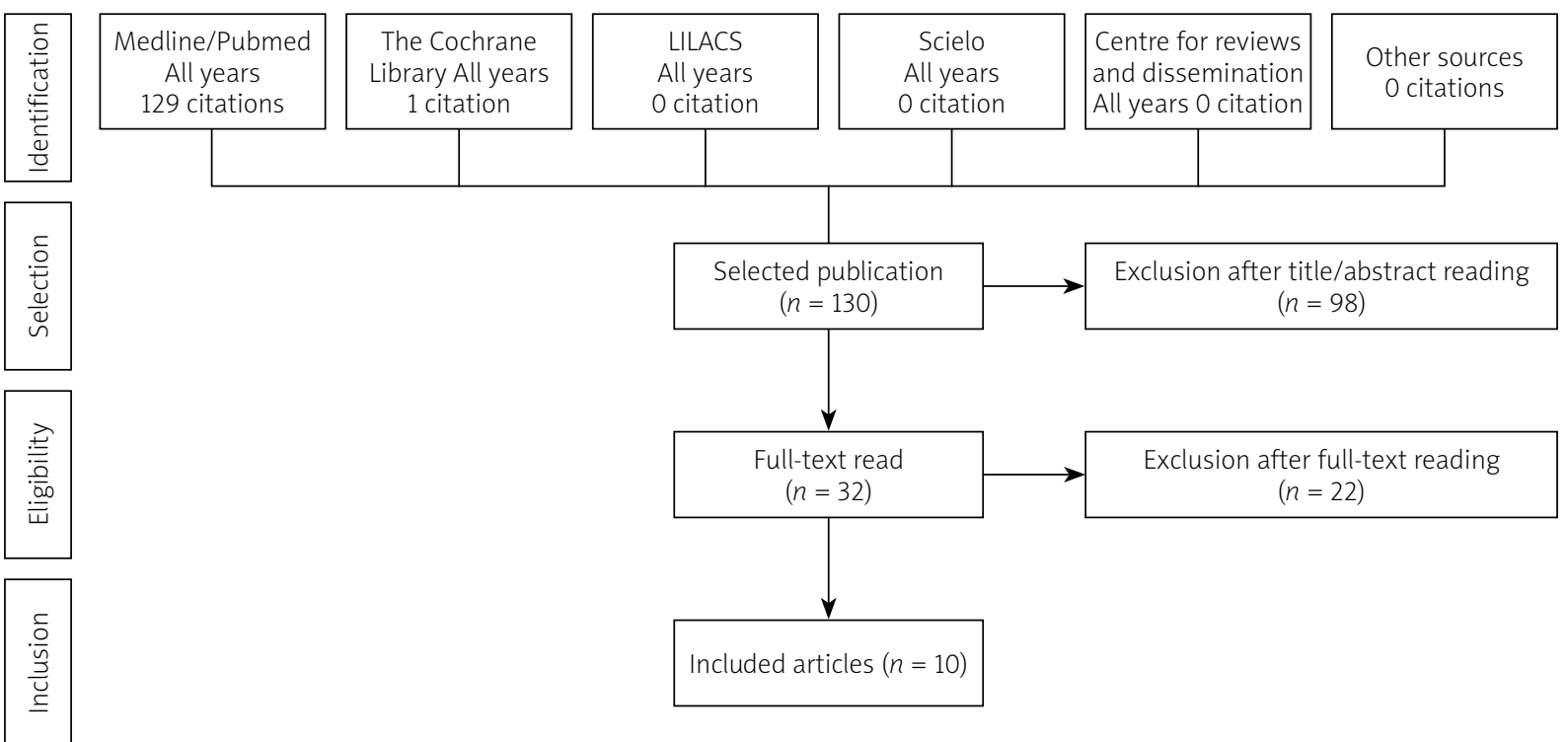

Figure 1. Systematic review flow diagram 
Table II. Characteristics of selected studies and clinical profile of patients

\begin{tabular}{|c|c|c|c|c|c|c|}
\hline Author, year & Local & Population & Intervention & Comparator & $\begin{array}{l}\text { Study } \\
\text { design }\end{array}$ & Follow-up \\
\hline $\begin{array}{l}\text { Okanobu, } \\
2020[16]\end{array}$ & Japan & $\begin{array}{l}78 \text { patients with } \\
\text { endoscopically confirmed EE }\end{array}$ & $\begin{array}{l}\text { Vonoprazan } 20 \mathrm{mg} \\
\text { (initial treatment) } \\
\text { Vonoprazan } 10 \mathrm{mg} \\
\text { (maintenance } \\
\text { treatment) }\end{array}$ & Vonoprazan 10 mg & $\mathrm{RCT}$ & 12 weeks \\
\hline Xiao, 2020 [17] & Asia & $\begin{array}{l}468 \text { patients with } \\
\text { endoscopically confirmed EE }\end{array}$ & Vonoprazan 20 mg & Lansoprazole 30 mg & $\mathrm{RCT}$ & 4 weeks \\
\hline $\begin{array}{l}\text { Mizuno, } 2019 \\
{[22]}\end{array}$ & Japan & $\begin{array}{c}50 \text { patients aged } \geq 20 \text { years, } \\
\text { with RE refractory to PPIs } \\
\text { who had no endoscopic } \\
\text { evidence of erosive } \\
\text { esophagitis after the } \\
\text { administration of VPZ } 20 \mathrm{mg} \\
\text { od/4 weeks }\end{array}$ & $\begin{array}{c}\text { Vonoprazan } 20 \mathrm{mg} \\
\text { (initial treatment) } \\
\text { Vonoprazan } 10 \mathrm{mg} \\
\text { (maintenance } \\
\text { treatment) }\end{array}$ & - & $\begin{array}{l}\text { Open-label, } \\
\text { prospective }\end{array}$ & 48 weeks \\
\hline $\begin{array}{l}\text { Ashida, } 2018 \\
{[23]}\end{array}$ & Japan & $\begin{array}{c}607 \text { patients } \geq 20 \text { years, } \\
\text { who presented with } \\
\text { endoscopically confirmed } \\
\text { healed EE after vonoprazan } \\
20 \mathrm{mg} \text { od/up to } 8 \text { weeks }\end{array}$ & $\begin{array}{l}\text { Vonoprazan } 10 \mathrm{mg} \\
\text { Vonoprazan } 20 \mathrm{mg}\end{array}$ & Lansoprazole 15 mg & $\mathrm{RCT}$ & 24 weeks \\
\hline $\begin{array}{l}\text { Kawai, } 2018 \\
{[24]}\end{array}$ & Japan & $\begin{array}{l}621 \text { patients (439 in } \\
\text { extension) with long-term } \\
\text { LDA-associated peptic ulcers }\end{array}$ & $\begin{array}{l}\text { Vonoprazan } 10 \mathrm{mg} \\
\text { Vonoprazan } 20 \mathrm{mg}\end{array}$ & Lansoprazole 15 mg & $\mathrm{RCT}$ & 24 weeks \\
\hline $\begin{array}{l}\text { Mizokami, } \\
2018[25]\end{array}$ & Japan & $\begin{array}{l}642 \text { patients receiving long- } \\
\text { term NSAID therapy, who are } \\
\text { at risk of peptic ulcer } \\
\text { recurrence }\end{array}$ & $\begin{array}{l}\text { Vonoprazan } 10 \mathrm{mg} \\
\text { Vonoprazan } 20 \mathrm{mg}\end{array}$ & Lansoprazole 15 mg & $\mathrm{RCT}$ & 24 weeks \\
\hline $\begin{array}{l}\text { Soiza, } 2017 \\
{[18]}\end{array}$ & Japan & $\begin{array}{c}19 \text { patients with PPI-resistant } \\
\text { EE }\end{array}$ & Vonoprazan 20 mg & Vonoprazan 40 mg & $\mathrm{RCT}$ & 8 weeks \\
\hline $\begin{array}{l}\text { Miwa, } 2017 \\
{[19]}\end{array}$ & Japan & $\begin{array}{c}482 \text { patients with gastric } \\
\text { ulcer and } 368 \text { patients with } \\
\text { duodenal ulcer }\end{array}$ & Vonoprazan 20 mg & Lansoprazole 30 mg & $\mathrm{RCT}$ & $\begin{array}{c}8 \text { weeks } \\
\text { (gastric } \\
\text { ulcer } \\
\text { cohort) } \\
6 \text { weeks } \\
\text { (duodenal } \\
\text { ulcer } \\
\text { cohort) }\end{array}$ \\
\hline $\begin{array}{l}\text { Ashida, } 2016 \\
{[20]}\end{array}$ & Japan & $\begin{array}{l}401 \text { patients } \\
\text { (305 in extension) with } \\
\text { endoscopically confirmed EE }\end{array}$ & $\begin{array}{l}\text { Vonoprazan } 10 \mathrm{mg} \\
\text { Vonoprazan } 20 \mathrm{mg}\end{array}$ & Lansoprazole 30 mg & $\mathrm{RCT}$ & 52 weeks \\
\hline $\begin{array}{l}\text { Ashida, } 2015 \\
{[21]}\end{array}$ & Japan & $\begin{array}{l}732 \text { patients } \geq 20 \text { years with } \\
\text { endoscopically confirmed EE }\end{array}$ & $\begin{array}{l}\text { Vonoprazan } 5 \mathrm{mg} \\
\text { Vonoprazan } 10 \mathrm{mg} \\
\text { Vonoprazan } 20 \mathrm{mg} \\
\text { Vonoprazan } 40 \mathrm{mg}\end{array}$ & Lansoprazole 30 mg & $\mathrm{RCT}$ & 8 weeks \\
\hline
\end{tabular}

hibit gastric acid secretion in humans and animals, beyond inhibition of $\mathrm{H}^{+}, \mathrm{K}^{+}$-ATPase via competitive interaction with $\mathrm{K}^{+}$site of the enzyme. Despite the favourable results, hepatic toxicity after prolonged administration led to the discontinuation of clinical studies. More recently, several SCH28080 derivative compounds were developed including vonoprazan, which is one of the drugs from P-CABs class available for use in clinical practice $[12,26]$.

Considering the initial concern about hepatic toxicity, we found 1 study in our systematic review that assessed the occurrence of this outcome. Xiao et al. reported safety events among patients with the diagnosis of erosive oesophagitis treated with P-CABs and PPIs. 
Table III. Overview of treatment-emergent adverse events and serious adverse events in studies using vonoprazan as initial therapy

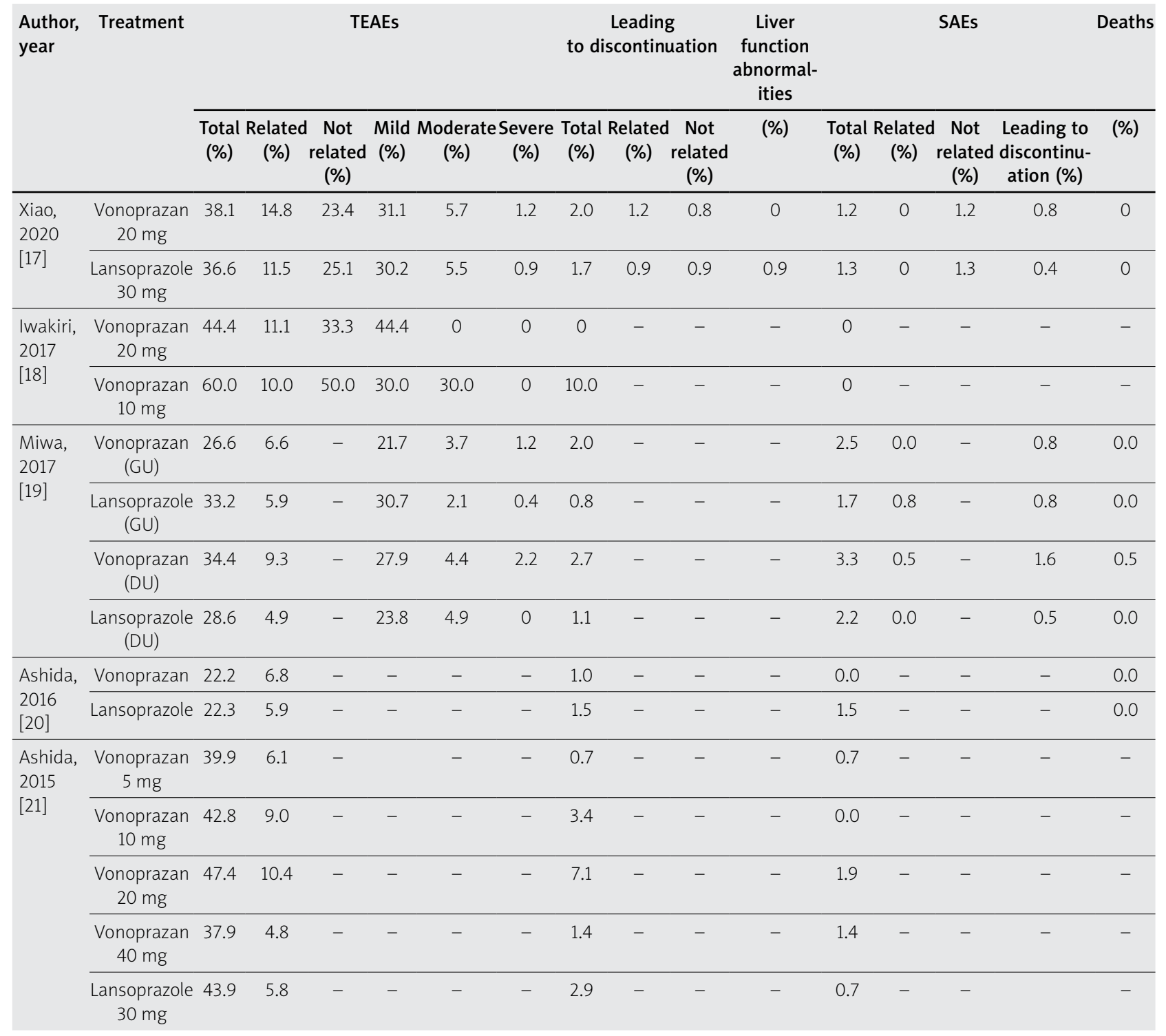

TEAE - treatment-emergent adverse events, SAES - serious adverse events, GU - gastric ulcer, DU - duodenal ulcer.

Liver function abnormalities were observed in $0.9 \%$ of the 235 patients treated with lansoprazole $30 \mathrm{mg}$, but no events were observed in the group treated with vonoprazan $20 \mathrm{mg}(n=244)$ [17].

The frequency of treatment-emergent adverse events in general ranged from $6.0 \%$ to $87.6 \%$, and those related to the treatment from $4.8 \%$ to $19.3 \%$. The great variability observed across the studies' estimates is related to whether the treatment was an initial or a maintenance therapy. Regarding serious adverse events, the occurrence ranged from $0.0 \%$ to $16.3 \%$ and from $0.0 \%$ to $2.0 \%$ for total and those related to treatment, respectively [16-25].
In general, the safety profile of vonoprazan was similar to that observed for lansoprazole, a potent PPI [17, 19-21, 23-25]. This finding confirms previous data reported in the current literature. He et al. conducted a systematic review and meta-analysis to compare the efficacy, safety, and tolerance of vonoprazan with PPIs in the treatment of peptic ulcers resulting from endoscopic submucosal dissection. The study reported a similarity between groups, with an insignificant relative risk for adverse events ( $R R=0.65 ; 95 \% \mathrm{Cl}: 0.31-1.38)$ [3]. Recently, Chen et al. also reported that vonoprazan and PPIs have similar safety profiles $(\mathrm{RR}=1.08 ; 95 \% \mathrm{Cl}$ : 0.96-1.22) in a meta-analysis considering patients with GERD [27]. 
Table IV. Adverse events with frequency > 5\% reported in at least 1 study, considering those using vonoprazan as initial therapy

\begin{tabular}{|c|c|c|c|c|c|c|c|c|c|c|c|}
\hline \multirow[t]{2}{*}{ Variable } & \multicolumn{2}{|c|}{ Xiao, 2020 [17] } & \multicolumn{2}{|c|}{$\begin{array}{c}\text { Iwakiri, } 2017 \\
{[18]}\end{array}$} & \multicolumn{2}{|c|}{$\begin{array}{c}\text { Ashida, } 2016 \\
{[20]}\end{array}$} & \multicolumn{5}{|c|}{ Ashida, 2015 [21] } \\
\hline & VPZ (\%) & LPZ (\%) & $\begin{array}{c}\text { VPZ } \\
20 \mathrm{mg} \\
(\%)\end{array}$ & $\begin{array}{c}\text { VPZ } \\
40 \mathrm{mg} \\
(\%)\end{array}$ & VPZ (\%) & LPZ (\%) & $\begin{array}{c}\text { VPZ } \\
5 \mathrm{mg} \\
(\%)\end{array}$ & $\begin{array}{c}\text { VPZ } \\
10 \mathrm{mg} \\
(\%)\end{array}$ & $\begin{array}{c}\text { VPZ } \\
20 \mathrm{mg} \\
(\%)\end{array}$ & $\begin{array}{c}\text { VPZ } \\
40 \mathrm{mg} \\
(\%)\end{array}$ & LPZ (\%) \\
\hline GI disorders & 18.4 & 19.1 & - & - & - & - & - & - & - & - & - \\
\hline Blood gastrin increased & 5.3 & 1.7 & - & - & - & - & - & - & - & - & - \\
\hline Gastric mucosal lesions & - & - & 0.0 & 10.0 & - & - & - & - & - & - & - \\
\hline Gastritis & - & - & 11.1 & 0.0 & - & - & - & - & - & - & - \\
\hline Oedema, peripheral & - & - & 11.1 & 0.0 & - & - & - & - & - & - & - \\
\hline Pyrexia & - & - & 0.0 & 10.0 & - & - & - & - & - & - & - \\
\hline Food allergy & - & - & 0.0 & 10.0 & - & - & - & - & - & - & - \\
\hline Fall & - & - & 0.0 & 10.0 & - & - & - & - & - & - & - \\
\hline Ligament sprain & - & - & 0.0 & 10.0 & - & - & - & - & - & - & - \\
\hline Flank pain & - & - & 0.0 & 10.0 & - & - & - & - & - & - & - \\
\hline Muscular weakness & - & - & 0.0 & 10.0 & - & - & - & - & - & - & - \\
\hline Skin papilloma & - & - & 0.0 & 10.0 & - & - & - & - & - & - & - \\
\hline Epistaxis & - & - & 11.1 & 0.0 & - & - & - & - & - & - & - \\
\hline Rhinalgia & - & - & 11.1 & 0.0 & - & - & - & - & - & - & - \\
\hline Psoriasis & - & - & 11.1 & 0.0 & - & - & - & - & - & - & - \\
\hline Infections and infestations & - & - & - & - & 6.3 & 7.4 & - & - & - & - & - \\
\hline Nasopharyngitis & - & - & - & - & - & - & 8.1 & 10.3 & 9.7 & 8.3 & 10.1 \\
\hline
\end{tabular}

VPZ - vonoprazan, LPZ - lansoprazole.

Table V. Overview of treatment-emergent adverse events and serious adverse events in studies using vonoprazan as maintenance therapy

\begin{tabular}{|c|c|c|c|c|c|c|c|c|}
\hline \multirow[t]{2}{*}{ Author, year } & \multirow[t]{2}{*}{ Treatment } & \multicolumn{2}{|c|}{ TEAEs } & \multirow{2}{*}{$\begin{array}{c}\text { Leading to } \\
\text { discontinuation } \\
\text { Total }(\%)\end{array}$} & \multirow{2}{*}{$\begin{array}{l}\text { Liver function } \\
\text { abnormalities } \\
\text { (\%) }\end{array}$} & \multicolumn{2}{|c|}{ SAEs } & \multirow{2}{*}{$\begin{array}{l}\text { Deaths } \\
\text { (\%) }\end{array}$} \\
\hline & & $\begin{array}{c}\text { Total } \\
(\%)\end{array}$ & $\begin{array}{l}\text { Related } \\
\text { (\%) }\end{array}$ & & & $\begin{array}{l}\text { Total } \\
(\%)\end{array}$ & $\begin{array}{l}\text { Related } \\
(\%)\end{array}$ & \\
\hline Mizuno, 2019 [22] & Vonoprazan 10 mg & 6.0 & 6.0 & - & - & 0 & - & 0 \\
\hline \multirow[t]{3}{*}{ Ashida, 2018 [23] } & Vonoprazan 10 mg & 54.0 & 10.4 & 2.5 & - & 2.5 & & 0 \\
\hline & Vonoprazan 20 mg & 58.8 & 10.3 & 3.9 & - & 2.0 & & 0 \\
\hline & Lansoprazole 30 mg & 51.2 & 11.4 & 4.0 & - & 2.0 & & 0 \\
\hline \multirow[t]{3}{*}{ Kawai, 2018 [24] } & Vonoprazan 10 mg & 87.6 & 16.3 & 7.9 & - & 16.3 & 2.0 & 0.5 \\
\hline & Vonoprazan 20 mg & 87.1 & 19.3 & 7.4 & - & 15.8 & 2.0 & 0 \\
\hline & Lansoprazole 30 mg & 84.8 & 24.4 & 9.2 & - & 14.7 & 1.4 & 0 \\
\hline \multirow{3}{*}{$\begin{array}{l}\text { Mizokami, } 2018 \\
\text { [25] }\end{array}$} & Vonoprazan 10 mg & 84.4 & 17.4 & 4.1 & - & 8.3 & 0.9 & - \\
\hline & Vonoprazan 20 mg & 82.5 & 17.5 & 12.7 & - & 14.2 & 0.9 & - \\
\hline & Lansoprazole 30 mg & 88.1 & 19.0 & 7.6 & - & 8.6 & 0 & - \\
\hline
\end{tabular}

TEAE - treatment-emergent adverse events, SAEs - serious adverse events.

All the studies included in this review were conducted in eastern countries. This may be pointed out as a matter of concern because populations from such countries have slower metabolizers and the safety profile may differ from that in western populations [28]. Jenkins et al. conducted 2 phase I studies in order to evaluate the safety, tolerability, pharmacokinetics, and pharmacodynamics of TAK-438 in healthy Japanese and non-Japanese men. Treatment-emergent adverse events were observed among 9 of 60 subjects in the Japanese cohort and in 
Table VI. Adverse events with frequency > 5\% reported in at least 1 study, considering those using vonoprazan as maintenance therapy

\begin{tabular}{|c|c|c|c|c|c|c|c|c|c|}
\hline \multirow[t]{2}{*}{ Variable } & \multicolumn{3}{|c|}{ Ashida, 2018 [23] } & \multicolumn{3}{|c|}{ Kawai, 2018 [24] } & \multicolumn{3}{|c|}{ Mizokami, 2018 [25] } \\
\hline & $\begin{array}{c}\text { Vono- } \\
\text { prazan } \\
10 \mathrm{mg}(\%)\end{array}$ & $\begin{array}{c}\text { Vono- } \\
\text { prazan } \\
20 \mathrm{mg} \mathrm{( \% )}\end{array}$ & $\begin{array}{l}\text { Lansopra- } \\
\text { zole } \\
30 \mathrm{mg}(\%)\end{array}$ & $\begin{array}{c}\text { Vono- } \\
\text { prazan } \\
10 \mathrm{mg}(\%)\end{array}$ & $\begin{array}{c}\text { Vono- } \\
\text { prazan } \\
20 \mathrm{mg}(\%)\end{array}$ & $\begin{array}{l}\text { Lansopra- } \\
\text { zole } \\
30 \mathrm{mg}(\%)\end{array}$ & $\begin{array}{c}\text { Vono- } \\
\text { prazan } \\
10 \mathrm{mg} \mathrm{( \% )}\end{array}$ & $\begin{array}{c}\text { Vono- } \\
\text { prazan } \\
20 \mathrm{mg}(\%)\end{array}$ & $\begin{array}{l}\text { Lansopra- } \\
\text { zole } \\
30 \mathrm{mg}(\%)\end{array}$ \\
\hline Nasopharyngitis & 16.8 & 13.2 & 13.9 & 29.7 & 31.2 & 31.3 & 32.1 & 27.8 & 29.0 \\
\hline Diarrhoea & 3.0 & 2.5 & 5.5 & 7.4 & 9.4 & 12.0 & 5.0 & 7.1 & 6.7 \\
\hline Constipation & 1.0 & 1.5 & 2.0 & 6.4 & 8.4 & 7.4 & 6.9 & 3.3 & 2.4 \\
\hline $\begin{array}{l}\text { Upper respiratory tract } \\
\text { inflammation }\end{array}$ & 4.0 & 2.0 & 1.5 & 5.9 & 6.4 & 4.6 & 5.5 & 6.6 & 3.3 \\
\hline Fall & 4.0 & 1.0 & 0.5 & 5.4 & 4.0 & 6.0 & 10.1 & 8.5 & 8.6 \\
\hline Back pain & 1.5 & 2.5 & 0.5 & 4.0 & 7.9 & 2.3 & 3.2 & 6.1 & 2.9 \\
\hline $\begin{array}{l}\text { Elevated creatine } \\
\text { phosphokinase }\end{array}$ & 2.0 & 2.9 & 1.0 & 4.0 & 5.4 & 4.6 & 4.1 & 3.3 & 5.2 \\
\hline Contusion & 2.5 & 1.0 & 1.5 & 3.5 & 3.5 & 6.5 & 7.8 & 6.6 & 9.5 \\
\hline Seasonal allergy & 2.0 & 1.0 & 1.0 & - & - & - & 3.7 & 7.1 & 3.8 \\
\hline Contact dermatitis & - & - & - & - & - & - & 3.7 & 5.7 & 2.9 \\
\hline
\end{tabular}

10 of 48 subjects in the UK cohort, while no serious adverse events were observed in both studies [29]. These data suggest that the metabolization profile of eastern populations has no impact on the safety of vonoprazan.

Despite the important results observed in the present study, some limitations should be highlighted. Language limits led us to exclude all publications in languages other than English, Portuguese, or Spanish. This may be considered as a major limitation of this study. In addition, a meta-analysis of the available data would provide more robust results to determine the outcome of interest.

\section{Conclusions}

The study findings suggest that vonoprazan has a favourable safety profile, especially when compared to PPIs (such as lansoprazole). Thus, considering efficacy data previously reported, it may be considered as a good and safe therapeutic option for the management of acid-related diseases.

\section{Acknowledgments}

Medical writing support was provided by Ana Carolina Padula from Origin Health Company and funded by Takeda Pharmaceuticals Brazil.

\section{Conflict of interest}

$D C$ has received fees as advisory board member for Takeda. JPPMF and GD has received fees as speaker for Takeda. JLSG and CYS are Takeda Pharmaceuticals Brazil full-time employees.

Takeda Pharmaceuticals Brazil funded this work.

\section{References}

1. Mejia A, Kraft WK. Acid peptic diseases: pharmacological approach to treatment. Expert Rev Clin Pharmacol 2009; 2: 295-314.

2. Di Mario F, Goni E. Gastric acid secretion: changes during a century. Best Pract Res Clin Gastroenterol 2014; 28: 953-65.

3. He HS, Li BY, Chen QT, et al. Comparison of the use of vonoprazan and proton pump inhibitors for the treatment of peptic ulcers resulting from endoscopic submucosal dissection: a systematic review and meta-analysis. Med Sci Monit 2019; 25: 1169-76.

4. Mori H, Suzuki H. Role of acid suppression in acid-related diseases: proton pump inhibitor and potassium-competitive acid blocker. J Neurogastroenterol Motil 2019; 25: 6-14.

5. Federação Brasileira de Gastroenterologia. Refluxo gastroesofágico: diagnóstico e tratamento. Projeto Diretrizes. São Paulo: AMB; CFM; 2003; 18.

6. World Gastroenterology Organisation (WGO). Perspectiva mundial sobre a doença do refluxo gastroesofágico. In: World Gastroenterology Organisation Global Guidelines DRGE. 2015; 1-38.

7. Federação Brasileira de Gastroenterologia. Úlcera Péptica. Projeto Diretrizes. São Paulo: AMB; CFM; 2003; 12.

8. The National Institute for Health and Care Excellence (NICE). Managing peptic ulcer disease in adults. Vol. 37, NICE Pathways. 2020; 56hn1-4.

9. Martinucci I, Blandizzi C, Bodini G, et al. Vonoprazan fumarate for the management of acid-related diseases. Expert Opin Pharmacother 2017; 18: 1145-52.

10. Hunt RH, Scarpignato C. Potassium-competitive acid blockers (P-CABs): are they finally ready for prime time in acid-related disease? Clin Transl Gastroenterol 2015; 6: e119-4.

11. Inatomi N, Matsukawa J, Sakurai Y, et al. Potassium-competitive acid blockers: advanced therapeutic option for acid-related diseases. Pharmacol Ther 2016; 168: 12-22. 
12. Rawla P, Sunkara T, Ofosu A, et al. Potassium-competitive acid blockers - are they the next generation of proton pump inhibitors? World J Gastrointest Pharmacol Ther 2018; 9: 63-8.

13. Leonardo R. PICO: Model for Clinical Questions Evidence Based Medicine and Practice. Evid Based Med Pr 2018; 4: 1-2.

14. The Cochrane Collaboration. RoB 2 Guidance: Parallel Trial. 2019; 1-24.

15. Joanna Briggs Institute. Critical appraisal tools [Internet]. [cited 2021 Jul 9]. Available from: https://jbi.global/critical-appraisal-tools

16. Okanobu H, Kohno T, Mouri R, et al. Efficacy of vonoprazan $10 \mathrm{mg}$ compared with $20 \mathrm{mg}$ for the initial treatment in patients with erosive esophagitis: a randomized pilot study. Esophagus 2021; 18: 669-75.

17. Xiao Y, Zhang S, Dai N, et al. Phase III, randomised, double-blind, multicentre study to evaluate the efficacy and safety of vonoprazan compared with lansoprazole in Asian patients with erosive oesophagitis. Gut 2020; 69: 224-30.

18. Soiza RL, Donaldson AIC, Myint PK. Vaccine against arteriosclerosis: an update. Ther Adv Vaccines 2018; 9: 259-61.

19. Miwa H, Uedo N, Watari J, et al. Randomised clinical trial: efficacy and safety of vonoprazan vs. lansoprazole in patients with gastric or duodenal ulcers - results from two phase 3, non-inferiority randomised controlled trials. Aliment Pharmacol Ther 2017; 45: 240-52.

20. Ashida K, Sakurai Y, Hori T, et al. Randomised clinical trial: vonoprazan, a novel potassium-competitive acid blocker, vs. lansoprazole for the healing of erosive oesophagitis. Aliment Pharmacol Ther 2016; 43: 240-51.

21. Ashida K, Sakurai Y, Nishimura A, et al. Randomised clinical trial: a dose-ranging study of vonoprazan, a novel potassium-competitive acid blocker, vs. lansoprazole for the treatment of erosive oesophagitis. Aliment Pharmacol Ther 2015; 42: 685-95.

22. Mizuno H, Nishino M, Yamada K, et al. Efficacy of vonoprazan for 48-week maintenance therapy of patients with healed reflux esophagitis. Digestion 2020; 101: 411-21.

23. Ashida K, Iwakiri K, Hiramatsu N, et al. Maintenance for healed erosive esophagitis: phase III comparison of vonoprazan with lansoprazole. World J Gastroenterol 2018; 24: 1550-61.

24. Kawai T, Oda K, Funao N, et al. Vonoprazan prevents low-dose aspirin-associated ulcer recurrence: randomised phase 3 study. Gut 2018; 67: 1033-41.

25. Mizokami Y, Oda K, Funao N, et al. Vonoprazan prevents ulcer recurrence during long-term NSAID therapy: randomised, lansoprazole-controlled non-inferiority and single-blind extension study. Gut 2018; 67: 1042-51.

26. Inatomi N, Matsukawa J, Sakurai Y, et al. Potassium-competitive acid blockers: advanced therapeutic option for acid-related diseases. Pharmacol Ther 2016; 168: 12-22.

27. Cheng Y, Liu J, Tan X, et al. Direct comparison of the efficacy and safety of vonoprazan versus proton-pump inhibitors for gastroesophageal reflux disease: a systematic review and meta-analysis. Dig Dis Sci 2021; 66: 19-28.

28. Lo C, Nguyen S, Yang C, et al. Pharmacogenomics in Asian subpopulations and impacts on commonly prescribed medications. Clin Transl Sci 2020; 13: 861-70.
29. Jenkins H, Sakurai Y, Nishimura A, et al. Randomised clinical trial: safety, tolerability, pharmacokinetics and pharmacodynamics of repeated doses of TAK-438 (vonoprazan), a novel potassium-competitive acid blocker, in healthy male subjects. Aliment Pharmacol Ther 2015; 41: 636-48.

Received: 17.11 .2021

Accepted: 16.12 .2021 